November 2021

\title{
Enhancing Critical Thinking Skills and Dispositions Through Community Dialogue in an Academic Writing Programme
}

Sylvia S C Sim

National University of Singapore, elcsimsc@nus.edu.sg

Follow this and additional works at: https://digitalcommons.georgiasouthern.edu/ij-sotl

\section{Recommended Citation}

Sim, Sylvia S C (2021) "Enhancing Critical Thinking Skills and Dispositions Through Community Dialogue in an Academic Writing Programme," International Journal for the Scholarship of Teaching and Learning: Vol. 15: No. 2, Article 14.

Available at: https://doi.org/10.20429/ijsotl.2021.150214 


\title{
Enhancing Critical Thinking Skills and Dispositions Through Community Dialogue in an Academic Writing Programme
}

\begin{abstract}
The ability to think and write critically is a core outcome in higher education. Many universities provide writing programs for undergraduates to develop sound argumentation skills and build the foundation to engage in academic conversations. Still many students struggle with academic writing. This paper argues that teaching using instructional frameworks is not sufficient; learning will be more effective when situated within a community of practice. Drawing from the learning experiences of students who participated in a community-based activity in a freshmen academic writing class in Singapore, I share my insights on how reframing learning from a structure-driven approach to a community-based experience had enhanced learning dispositions and outcomes. Results show that when learners viewed academic writing as a socially situated practice, and not a task to be completed to fulfil academic requirements, the dispositions needed for critical thinking were honed to drive them towards writing with more criticality.
\end{abstract}

\section{Keywords}

Academic writing, argumentation, critical thinking skills, critical thinking dispositions, community of learners in practice

\section{Creative Commons License} c) (i) $(\Theta$

This work is licensed under a Creative Commons Attribution-Noncommercial-No Derivative Works 4.0 License. 
IJ-SoTL, Vol. 15 [2021], No. 2, Art. 14

\title{
Enhancing Critical Thinking Skills and Dispositions Through Community Dialogue in an Academic Writing Programme
}

\author{
Sylvia S C Sim \\ National University of Singapore \\ Received: 8 June 202I;Accepted: 9 August 202I
}

\begin{abstract}
The ability to think and write critically is a core outcome in higher education. Many universities provide writing programs for undergraduates to develop sound argumentation skills and build the foundation to engage in academic conversations. Still many students struggle with academic writing. This paper argues that teaching using instructional frameworks is not sufficient; learning will be more effective when situated within a community of practice. Drawing from the learning experiences of students who participated in a community-based activity in a freshmen academic writing class in Singapore, I share my insights on how reframing learning from a structure-driven approach to a community-based experience had enhanced learning dispositions and outcomes. Results show that when learners viewed academic writing as a socially situated practice, and not a task to be completed to fulfil academic requirements, the dispositions needed for critical thinking were honed to drive them towards writing with more criticality.
\end{abstract}

\section{INTRODUCTION}

Most universities provide undergraduates with academic writing support to build the necessary foundation to engage in academic conversations. With these skills and dispositions, students are better positioned to explore and question "knowledge" and contribute to ongoing academic discourse (Allison \& Wu, 200I). To empower writers to think and write critically with respect, truthfulness and to add academic worth (Liu \& McCabe, 20I8), they need to acquire more than just an understanding on how to do so; they need to have an appreciation and experience of sound argument to effectively engage in what Burbules and Berk (1999) term as the "practice of criticality" (p.59) that presents students with the "possibility of thinking otherwise", a fundamental element of academic writing. To achieve this, teachers of academic writing face the challenge of "help[ing] students negotiate the competing claims of self-assertion and self-effacement, individual creativity and institutional authority, personal commitment, and community expectations" (Hyland \& Sancho-Guinda, 20I2, p. 249) to eventually find and develop their voice or stance. Andrews (2010) argues that argumentation is "so deeply embedded" (p. I) in the university curriculum that it is imperative that both educators and students are able to navigate "the choreography of argument" ( $p$. 39). He cautions against adopting a one-size-fits-all approach to cater to the diverse needs of students across various disciplines.

There are concerns about the challenges of teaching argumentation skills effectively. One of the issues raised by Wingate (2012) is that academic writing is poorly understood and inadequately taught by academic tutors, leaving students to grapple with the complexities. Instead of leaving students to acquire a critical perspective as lessons progressed, she suggests educators adopt strategies that help students first to understand underlying conventions and practices. The "Academic Literacies" approach (Lea and Street, 2006) goes further to shift the focus from production to practice by taking both epistemological issues and social processes into consideration. To be effective, students need to "switch their writing styles and genres between one setting and another to deploy a repertoire of literacy practices appropriate to each setting, and to handle the social meanings and identities that each evokes" (p.368).
Participation in social practice requires (student) writers to engage in argumentation, a metacognitive process that comprises both (critical thinking) skills and dispositions (Dwyer, Hogan, Harney \& Kavanagh, 2017). Therefore, learners need to cultivate dispositional characteristics and habits of mind (Sullivan, 2014) in order to develop a "critical spirit" (Siegel, 1988). More needs to be done to motivate students to exercise the criticality needed to deal with the complexities of academic writing. This requires more than just cognitive abilities; to be engaged, students need to experience argumentation as an academic practice to appreciate the intricacies of argumentative discourse. "Knowing what to do is not enough. Knowing how to do it is still not enough. Students must want to learn if they are to use the knowledge, strategies, and skills." (McKeachie \& Hofer, 2002, p. 208).

This can be challenging in the Singapore context where, prior to university education, most students learn in teacher-fronted classrooms where instruction is mainly monological. In teacher-fronted classrooms where the focus is on transmitting knowledge, students tend to adopt a surface approach to learning resulting in lower quality learning outcomes (Trigwell, Prosser, \& Waterhouse, 1999). Tan (2017) argues the teaching of critical thinking in Singapore schools is limited by culturally defined expectations of "teachers as knowledge transmitters and students as passive learners" and "the notion of critical thinking as adversarial" (p. 998) make it difficult for learners to develop the criticality needed for higher-level studies.

This study examines how situating learning within an academic writing community will provide opportunities for authentic engagement in practice. In a culture where learning is mainly "teacher-driven", it creates a space to induct learners into the practice. Enacting argument as a social activity within a community provides a conducive learning environment for learners to cultivate their critical thinking dispositions and hone their skills. Such a strategy moves learning from gaining a normative understanding of identifying and applying conventions to taking a more transformational approach (Lillis \& Scott, 2007), one that taps on students' own resources as "legitimate tools" (p. 13) to facilitate the discovery of different perspectives and alternative ways of meaning making. While research has acknowledged the 
benefits of community in post-graduate research writing groups (Aitchinson \& Lee, 2006), not much work is done on the adoption of such initiatives at the undergraduate level, especially in the freshmen year. Creating such opportunities at this early stage gives them a head-start by equipping them with these crucial skills and dispositions to transition effectively from pre-university to undergraduate studies.

\section{BACKGROUND (CONTEXT)}

The study involved ninety first-year humanities and social sciences students in a Singapore university enrolled in an academic writing module that aimed to facilitate the transition from high school writing to academic writing in university studies. The course objectives of the twelve-week program were to improve these skills:

- Read and critically evaluate sources.

- Exercise judgment to arrive at a justified position.

- Construct arguments to support this position.

- Manage alternative views by refuting or qualifying their claims.

- Acknowledge and cite sources accurately.

To help students understand the underlying conventions and practices, the first six weeks of the program required student to analyse and de-construct discipline-specific text. They identified relevant features of academic writing and applied these to their own writing. Students submitted a research proposal in the third week, followed by a literature review in the sixth. Scaffolding was provided in the form of detailed formative feedback and close guidance from the teacher. Students refined their drafts before the final submission in each instance. These assignments made up fifty-five percent of their final grade.

In the second half of the program, students worked independently on a final research paper that carried the remaining forty-five percent weightage. There was a noticeable drop in confidence as many seemed to have difficulties bridging the knowledge-practice gap.Without the teacher's guidance, many struggled with applying what they had learnt in the past six weeks.

This concurs with what Aitchison and Lee (2006) observed in their work with graduate students. At the stage of articulation, students faced the difficulty of having to grapple with "thinking, learning, knowing, engaging, positioning, becoming and writing' simultaneously (p. 268). Similarly, many of these freshmen had limited experience in writing a full-fledged research paper. Despite having completed six weeks of the academic writing curriculum, they had difficulties managing when the demands of thinking and writing became intertwined. Coupled with the need to attain a good grade a priority, many reverted to a mechanical way of putting an essay together, dictated by external instructions instead of exercising critical judgment acquired by understanding of the underlying conventions and practice. Indicative of this was that more students were asking questions like:

How many sources do I need to use?

How many counter arguments must I have?

How do I know if my thesis statement is strong enough to be convincing?

I am worried that I am not able to find sufficient counter arguments.

Is it wise to present a counter argument that is too strong?
What if I cannot defend my position?

These questions reflected "a narrow-syllabus-bound attitude" to learning that reflects a "surface" learning approach, what Beaten et. Al (20I0) claim could be "motivated by a fear of failure and a desire to keep out of trouble as much as possible." (p. 244). It also showed a need for teacher-directed learning. In this context, the high weightage of the research paper assignment and the fear of not doing well became barriers to students transferring what they had learnt from their earlier writing experiences to writing the research paper. Scholarly research indicates that a preoccupation with grades reduces learning effectiveness as it is difficult to develop a love for learning (Dahlgren et al. 2009) and learners become reluctant to take risks and exercise critical and creative thinking (Demirel 2009).

It was clear that more was needed to encourage students to go beyond superficial application and motivate them to tap on their tacit knowledge to argue effectively in their research paper. An authentic and engaging learning experience in the form of a peer review situated in a community of practice was an attempt to make students look beyond grades, and to re-ignite the disposition that drove criticality in their writing.

The community-based feedback (CBF) exercise was designed to create a safe space for students to participate in meaningful academic discourse. Rather than rely on just on teacher feedback, the CBF exercise leveraged on community involvement in the form of mutual peer feedback to shape dispositions and drive learning, thus motivating students to be authentically engaged in practice. While writing is generally perceived as an individual activity, it is not a solitary pursuit. Aitchison and Lee (2006) who work with post-graduate research writing groups, call for writing as a social, situated practice to be embraced in research education. They argue that having peer writing groups provides a learning environment that helps writers form their identity as writers within a community of practice.

\section{METHOD}

The CBF exercise encouraged students to interact meaningfully with others in their community to tap on mutual support as each worked individually on their research paper. Such interactions sought to bring about a shift in dispositions towards critical engagement. This activity comprised a series of outline presentations cum peer feedback and took place in weeks seven to nine in the twelve-week program. Each presentation was followed by a questions and answer/discussion session, during which presenters and peer reviewers clarified, challenged and defended views, both face-to-face and online (see Figure I). These sessions were not graded.

There were ninety students divided into six communities of learners in practice (CLPs), with each having fifteen participants. Communities of learners in practice (CLP) in this study is an adaptation of Wenger's (20I I) communities of practice (CoP) defined as "groups of people who share a concern or a passion for something they do and learn how to do it better as they interact regularly." While Wenger's CoPs occur mostly in professional fields (eg. nursing and teaching) and comprise newcomers learning from the more experienced, members in CLPs were mainly newcomers. Nonetheless, the dynamics of a CoP were still observable in a CLP, driven by the three essential components of CoP (Wenger, 20I I) which are: 


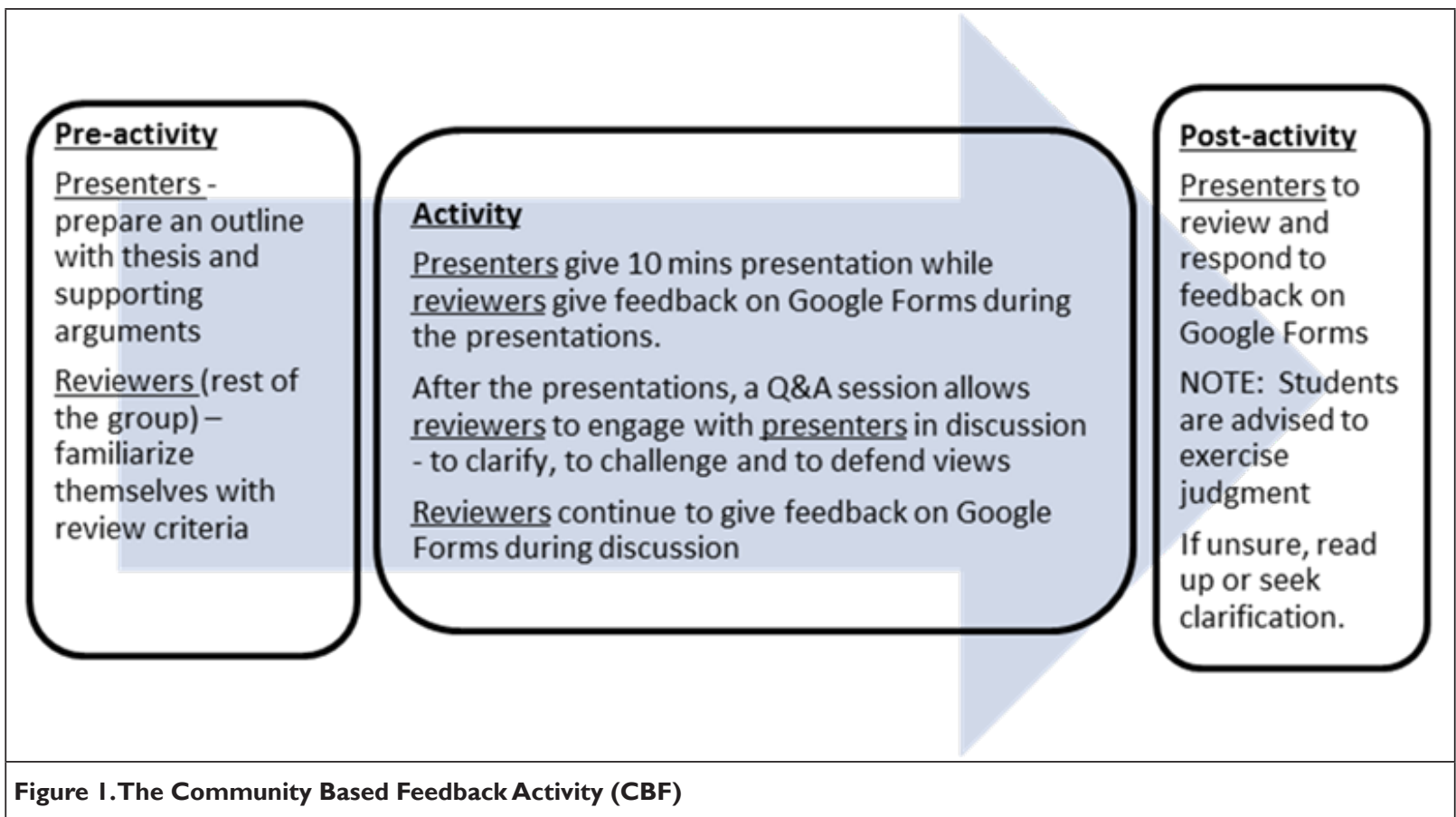

I. Domain - an area of interest which, in this context, refers to argumentation in academic writing.

2. Community - members in the domain that interact and engage in shared activities, in this context, members of a tutorial group.

3. Practice - what the members practice in common, in this context, writing an academic research essay. Although the research paper is an individual task, members rely on one another to achieve better quality work. Like in CoPs, the focus of this CPL is knowledge management with members using dialogue as a vehicle for learning.

Feedback was based on a set of evaluation criteria based on threshold concepts of argumentation as shown in the Google Form in Figure 2. Meyer and Land (2006) defined threshold concepts as key principles that define a subject, and once acquired, result in a conceptual shift that transform knowledge and take the learner cross the "threshold". The feedback was given both faceto-face and on the Google Form platform to maximise opportunities for the community to connect.

These sessions took place in a conference style setting to encourage face-to-face interaction. After each presentation, faceto-face peer evaluation took place in the form of a Q\&A cum discussion session. The aim was to provide two-way communication and create an interactive discussion through which comments made from their Google Forms during the presentation can be verbalised and debated. Having to defend and forward positions drew students into these discussions, elevating the feedback process increasing active engagement. After each session, participants refined their comments and sent their Google Forms to the respective presenters for reference.

By the end of the exercise, each participant would have accrued the experience of having participated in fifteen conversations during which he/she practiced argumentation as a social process that facilitated sharing, negotiation and the co-construction of meaning. As the student interacted with others in the community, he/she evaluated alternative positions in order to situate and shape his/her own, resulting in enculturation into the practice. Topping (1998), after reviewing 109 research papers on peer assessment, concluded that it yields cognitive and meta-cognitive benefits for both the assessor and the assessed. Participating in the CBF involved everyone as assessor or assessed creating opportunities for what Halpern (1999) terms as "metacognitive monitoring" (p.73) defined as "what (one) knows about what one knows". Verbalising the normally private thinking that goes on in crafting arguments in the form of feedback, and then drawing

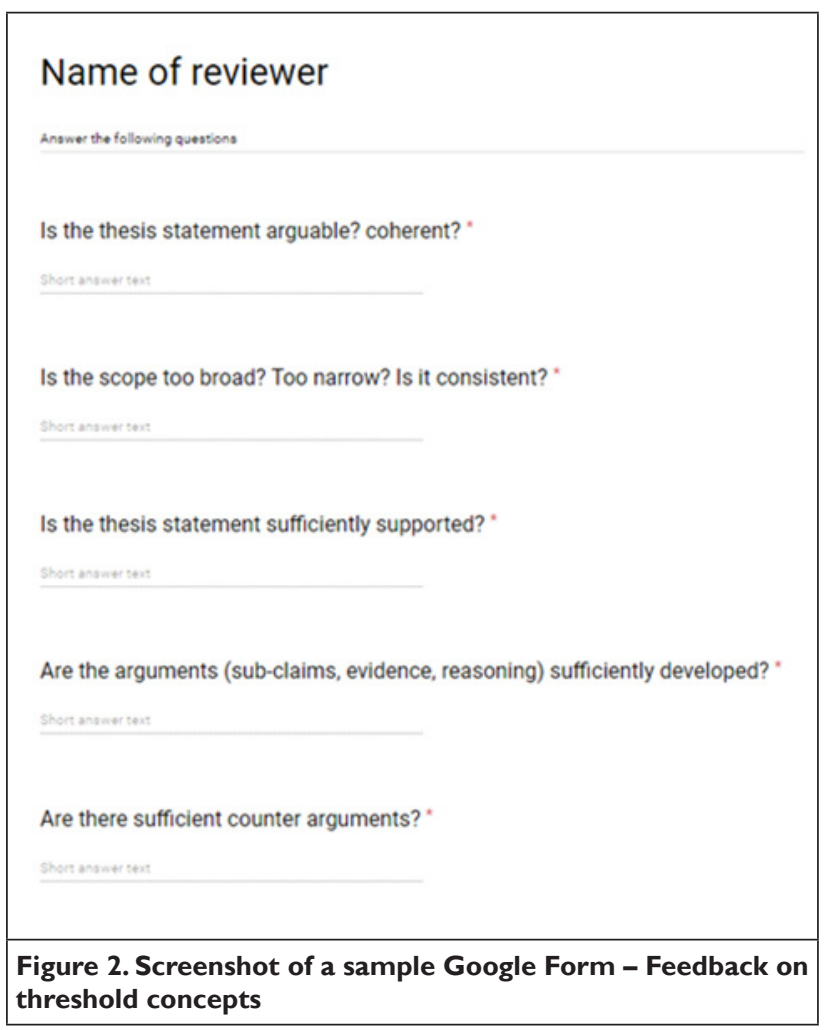


others into the conversation go a long way to help these novice researchers question and shape their own perceptions, thus improving their thinking and writing. Hoffman (2016) argues that such meaningful interaction not only promotes cognitive development, but also shapes attitudes and dispositions that groom learners who are open and willing to learn.

This study investigates how learning in CLP enhanced the learning experience of its members as they engaged in meaningful conversations with the community to negotiate the complexities of writing a research paper. It examines how the dynamics helped to shift learners' dispositions to deepen learning. This paper argues that situating learning in a CLP positively shapes learners' critical thinking dispositions that motivates them to better put into practice their thinking and writing skills.

Pre and post activity surveys, comprising both rating and open-ended questions, were used to investigate how the CBL had enhanced the learning experience. Responses to the open-ended question on students' concerns prior to the CBF (in the pre-activity survey), and the question on what students found useful (in the post-activity survey) were coded and matched to highlight any shifts in perceptions. Teacher observation supplemented the survey data to give a more complete picture.

\section{RESULTS AND ANALYSIS \\ Managing expectations, gaining confidence}

CLPs are driven by its members' desire to work with and learn from others in the community. For this to happen, students need to feel that they are in a safe space. Tan (2017) found that, in the Singapore context, students may perceive critical thinking to be adversarial and be more reluctant to participate. The CFB exercise created a non-threatening environment to manage students' expectation and to give them more confidence.

Instead of trying to cope on their own, participants found that listening to others share their ideas and experiences was reassuring. Knowing that others were also faced similar issues helped them to manage their expectations of their own performance.Twenty-eight percent of respondents strongly agreed, and forty-four percent agreed that knowing they were not the only ones facing problems gave them some reassurance (see Figure 3).
Learners appreciated the opportunities to observe what others did, and the experience encouraged them to reflect on their own learning. They also learnt from others who were more proficient. The following responses support this:

"It is useful to see how my peers come up with solutions."

“Learn from mistakes that my peers make."

"Learn from how others craft their outlines."

"Hearing others voice their thoughts gave me insights into how they have shaped their thoughts."

"Learning to spot weaknesses in others' work allows me to better critique mine."

"Have the opportunities to compare and contrast the quality of argument with those of our peers."

"It allows us to observe how others get their ideas, and allow us to apply it to our own argument."

“Learning from how others' write, and emulating their strengths."

In their study, Li and Steckelberg (2006) found that students found it helpful "to look at what others were doing, and some of them felt inspired by their peers work" (p.268) and this supports the social constructivist view of learning that sees cognitive development arising from social interaction with a more able member of society (Vygotsky, 1978).

Such metacognitive processes gave motivation to exercise judgment, resulting in them becoming more adaptive. The modelling and scaffolding as well as the support of the community gave learners the confidence to want to participate and put into practice what they had observed. In this way, learning in a CLP resulted in more learners indicating higher confidence levels of being able to apply the strategies (see Figure 4). There was a decrease from sixty-one to thirty-eight respondents who rated their confidence to be at levels 2 and 3, and an increase from thirty-nine to sixtytwo respondents showing higher confidence levels at 4 and 5 .

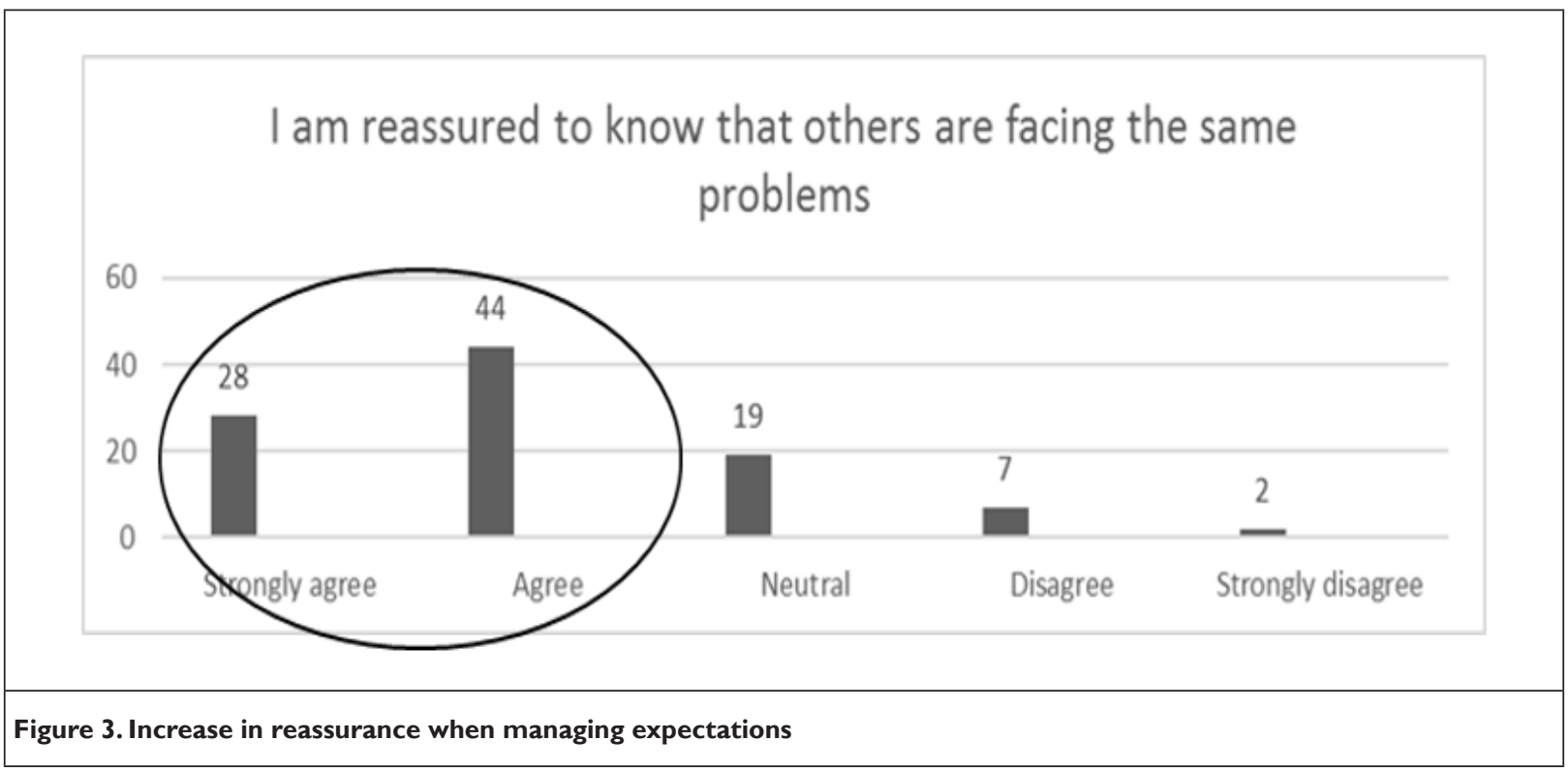




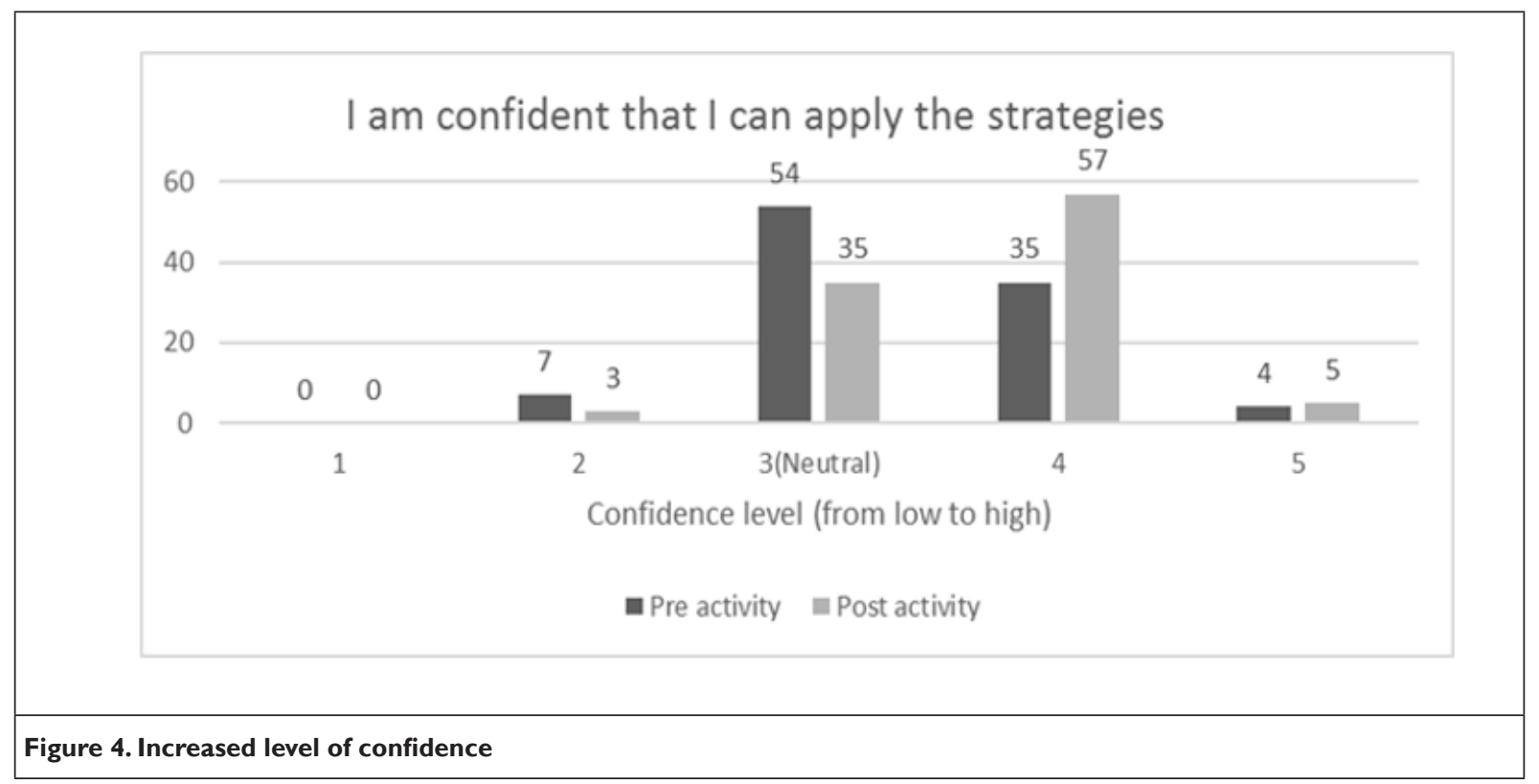

With increased confidence, learners are willing to take initiatives and risks to exercise judgment during these discussions, and in the writing of their research paper. Increased participation sharpened judgement and deepened learning, which in this context is defined as "the process whereby knowledge is created through ... the combination of grasping and transforming experience" (Kolb, I984, p. 4I). Such dialogic conversation in a community helped learners develop their tacit knowledge and provide scaffolding for less proficient members to be stretched beyond their current level towards their potential level of development. In this way, these novice writers were co-opted into the practice of academic writing to eventually perform what Shaughnessy (1977) terms "rituals and ways of winning arguments in academia".

An encouraging development observed was the subsequent spontaneous formation of informal sub-groups based on interest and needs. Such a ground-up initiative is perhaps indicative of the some of the learners' appreciation of the value of community interaction and that the responsibility of learning was gradually being devolved. These sub-groups resembled the research writing groups in Aitchison \& Lee's study (2006), described as being "explicitly negotiated, self-directed, evolving and dynamic and inherently responsive to group agendas and articulated needs.” (p. 27I)

\section{Developing Critical Thinking Dispositions}

It was found that participants in the CLPs were engaged in the types of interaction seen in CoPs. According to Wenger (20I I), it is through these interactions that communities develop their practice. For examples, please refer to Table I.

Perhaps more aligned with a cultural inclination towards group collectivism, students' responses showed an appreciation of such positive interdependence.According to Johnson and Johnson (2009), this results in promotive interaction which "occurs as individuals encourage and facilitate each other's efforts to accomplish the group's goals".Appreciating the value of such interaction increased mutual engagement, a key characteristic of practice (Wenger, 1998).

Evidence also showed a noticeable shift towards the learners' critical dispositions and their attitude towards learning. The California Critical Thinking Disposition Inventory (CCTDI) (Facione

Table I.Types of interaction (Community of Practice) CBF activities

\begin{tabular}{|c|c|}
\hline $\begin{array}{l}\text { Types of interaction as } \\
\text { suggested by Wenger (2011) }\end{array}$ & Examples from this case study \\
\hline Problem solving & $\begin{array}{l}\text { Presenter: Thank you for pointing out that the two } \\
\text { parts of my thesis are not coherent. Do you have } \\
\text { any suggestions on how I can link these elements? } \\
\text { Reviewer: I think perhaps instead of just listing } \\
\text { the two elements, consider the relationship. In } \\
\text { this case, I think perhaps the first element is the } \\
\text { result of the second? }\end{array}$ \\
\hline Request for information & $\begin{array}{l}\text { From a member of the community to the } \\
\text { presenter: That's an interesting source that would } \\
\text { support one of my claims. Could you please share } \\
\text { it with me? } \\
\text { From presenter to the community: I need sources } \\
\text { that provide alternative perspectives to this } \\
\text { argument. Has anyone come across any? Please } \\
\text { let me know. }\end{array}$ \\
\hline Seeking experience & $\begin{array}{l}\text { Presenter: Has anyone cited a source within a } \\
\text { source? Can you show me how to do it? }\end{array}$ \\
\hline Reusing assets & $\begin{array}{l}\text { Member of the community: I used a synthesis } \\
\text { table to help me with my literature review. This is } \\
\text { the way I have used it... }\end{array}$ \\
\hline Coordination and synergy & $\begin{array}{l}\text { From reviewer to presenter: I think my argument } \\
\text { can be strengthened if I reasoned the way you did. } \\
\text { And I have some sources which you might find } \\
\text { useful. Shall we get together can see how we can } \\
\text { help one another? }\end{array}$ \\
\hline Discussing developments & $\begin{array}{l}\text { Presenter: I am not sure where to go from here. } \\
\text { Can anyone help? Any suggestions? } \\
\text { Member of the community: Perhaps you could } \\
\text { approach it this way... }\end{array}$ \\
\hline Documentation & $\begin{array}{l}\text { Tutor: Can you please capture the feedback on } \\
\text { google forms for each presenter so that after the } \\
\text { session, he/she will have a record of what has } \\
\text { been raised and discussed? }\end{array}$ \\
\hline Visits & $\begin{array}{l}\text { Not applicable in this case because of the noture of } \\
\text { the "profession". This applies more to site visits } \\
\text { made by professions such as "nursing". }\end{array}$ \\
\hline $\begin{array}{l}\text { Mapping knowledge and } \\
\text { identifying gaps }\end{array}$ & $\begin{array}{l}\text { Presenter: That's a really interesting perspective } \\
\text { that I did not consider. While I somewhat agree } \\
\text { with your view, I think my opinion is also valid. } \\
\text { Now is there a way we can reconcile the two } \\
\text { views? Can we frame it differently? }\end{array}$ \\
\hline
\end{tabular}


\& Facione, 1995) describes the ideal critical thinking as having the following qualities:

- Self-confidence

- Inquisitiveness

- Open-mindedness

- Truth-seeking

- Systematicity

- Analyticity

- Maturity

Using these as criteria, the results of the investigation show that CBF has enhanced the communities' learning. Besides an increase in confidence, as was shown earlier, evidence from the study indicated a significant shift in students' attitude towards learning in terms of inquisitiveness, open-mindedness and truth-seeking.

Pre-activity responses showed that presenters felt anxious and there was a lack of confidence in handling differences in perspectives. Their focus was mainly on supporting their own position, rather than seeking truth, and there was little inquisitiveness (learning for the sake of learning). Feedback offering alternative perspectives were seen as threatening and was a source of concern (see Pre-activity comments in Table 2).

Table 2. Pre and post activity - shift in disposition (as presenters)

\begin{tabular}{|l|l|}
\hline Pre-activity (concerns raised) & Post-activity (what was useful) \\
\hline That my work is substandard & Learn from others and get ideas \\
\hline Having conflicting feedback & Opportunities to hear more views \\
\hline There is divided opinion on my work & $\begin{array}{l}\text { Provides us with opportunities to } \\
\text { compare quality of argument against } \\
\text { our peers }\end{array}$ \\
\hline $\begin{array}{l}\text { Don't know how to resolve issues } \\
\text { raised }\end{array}$ & $\begin{array}{l}\text { These sessions had been useful in } \\
\text { identifying my gaps }\end{array}$ \\
\hline Being hurt by negative feedback & $\begin{array}{l}\text { I can hear and evaluate better as part } \\
\text { of a learning community }\end{array}$ \\
\hline & $\begin{array}{l}\text { Helps me get other perspectives on my } \\
\text { paper (myopic to flaws after working } \\
\text { on it for a while) }\end{array}$ \\
\hline
\end{tabular}

After the CBF experience, results showed that as presenters, issues students previously viewed as concerns were now seen as opportunities for learning. They became more receptive to differing perspectives and viewed others' feedback positively as opportunities for further truth-seeking (see Post-activity in Table 2).

Pre-activity survey showed that as reviewers, students hesitated to offer feedback, concerned that their feedback might not be well-received. They did not want to be wrong and did not wanting to offend their peers. Inquisitiveness and open-mindedness were not motivating factors. (See Pre-activity comments in Table 3)

The post activity survey showed the dispositions moved towards inquisitiveness and open-mindedness, and students were more motivated by truth-seeking, moving away from earlier right/ wrong perspective (see Post-activity comments in Table 3).

Such a shift showed that learners were beginning to appreciate the academic dialogue, and as a result, had developed a better sense of their roles in the CLP.The CBF exercise had helped the community adopt a more collegial practice of argumentation that was more aligned with an Asian classroom. According to Tan (2017), such a non-threatening learning environment moti-

\begin{tabular}{|l|l||}
\hline \multicolumn{2}{|l||}{ Table 3. Pre and post activities - shift in disposition (as reviewers) } \\
\hline Pre-activity (concerns) & Post-activity (what was useful?) \\
\hline Not sure whether my opinions are right & $\begin{array}{l}\text { Give different perspectives on the same } \\
\text { topic }\end{array}$ \\
\hline My feedback might not be useful. & $\begin{array}{l}\text { I learn from my peers and their thought } \\
\text { processes }\end{array}$ \\
\hline $\begin{array}{l}\text { Imposing my perceptions and ideals on } \\
\text { others }\end{array}$ & $\begin{array}{l}\text { Listening to different perspectives was } \\
\text { refreshing and helped me a lot }\end{array}$ \\
\hline $\begin{array}{l}\text { Different points of view between the } \\
\text { reviewer and the writer }\end{array}$ & $\begin{array}{l}\text { Other perspectives make me } \\
\text { reconsider my judgment }\end{array}$ \\
\hline $\begin{array}{l}\text { That I may gave misunderstood the } \\
\text { argument }\end{array}$ & Clarify doubts with the inputs of others \\
\hline Hurting the morale of others & It is useful to see how my peers think \\
\hline Appear to be nit-picking & $\begin{array}{l}\text { Learn from the mistakes of my peers as } \\
\text { well as my own }\end{array}$ \\
\hline
\end{tabular}

vates students to engage and contribute, and participants take on the responsibility of helping others in the community improve, promoting an open learning culture that encourages participants to seek and offer honest and constructive feedback. In this context, such a learning environment created a synergy that fostered the desired learning dispositions needed to deepen learning.

\section{Moving towards criticality}

Creating space for learners to enact argument as a socially situated activity took the learning experience to the next level as learners participated in meaningful academic discourse during which they listened and evaluated alternative positions in order to situate and shape their own. Exposure to a variety of reasoned arguments reinforced threshold concepts and provided invaluable experience to perform the rules and practices of argumentation.

From these experiences, students developed systematicity. Facione et. al. (1995) defines it as "being organized, orderly, focused and diligent in inquiry" (p.7). Seventy-six percent of the presenters strongly agreed and agreed that presenting their outlines to the community was useful in helping them to crystalize their thoughts (see Figure 5).

Having to present to the community helped presenters develop stronger audience awareness, and this motivated them to adopt a more considered and organized disposition as shown in the following:

"Forced me to crystalize my thoughts instead of just having ideas."

"When presenting, ... verbalize and internalize (what I intend to write)."

"Allow me to apply theories to real life situations."

"To be able to verbalize our thoughts and ideas gives us an opportunity to critically analyze them instead of being absorbed in the writing process."

"The outline forces me to think through my argument, and not jump straight into it."

Greater audience awareness also helped learners to shift from merely knowing and mechanically applying to using judg- 


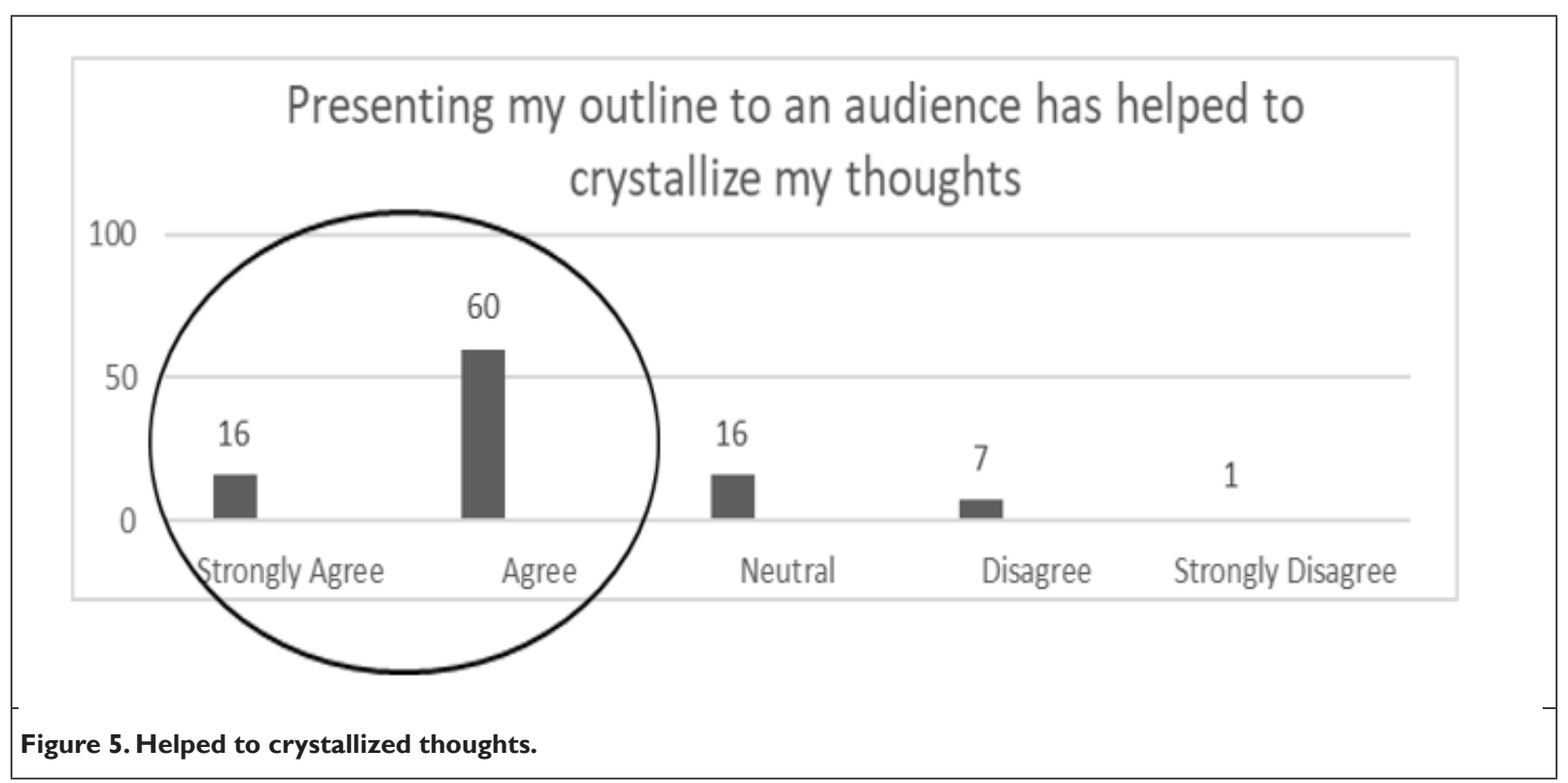

ment and being able to perform. These responses from the survey support this:

"Gives me the opportunity to refine my thoughts and in such a way that others can understand my points which help in the final paper as well."

"Useful in helping me construct and reason to convince others."

"Forces me to figure out a logical flow in each argument."

"Verbalizing our argument (to an audience) allowed me to be clearer."

"To know if my argument is clear from a third person point of view."

"Forced us to simplify concepts and ensure flow."

"Structure my thoughts well in a clear and concise manner."
The CBF exercise made the argumentation process more tangible. It provided "a setting in which individuals (would be able to) appreciate the relevance of noting and arguing against the other's claims, rather than just focusing solely on one's own position and the arguments that support it." (Felton \& Kuhn, 200I). These experiences helped learners acquire analyticity, defined by Facione et. al. (1995) as "prizing the application of reasoning and the use of evidence to solve problems, anticipating potential conceptual or practical difficulties, and consistently being alert to the need to intervene" (p. 7).

Students found that listening to presentations had helped them think critically (7I\%), spot their own weaknesses (7I\%) and think of solutions to their problems $(66 \%)$ when writing their research paper (see Figure 6).

At this stage, students had gone beyond just learning to write; The CBL exercise provided a context that encouraged openness and a comfortable space to encourage community dialogue in this "practice of criticality" (Burbules \& Berk, 1999). Evidence of this were indicated in the qualitative comments in the post-ac-



Figure 6. Usefulness of listening to presentations in CBL 
tivity question. Listening to others' perspectives was described as "insightful”, "refreshing" and "interesting”. Other comments include:

"Gives me different perspectives of how others view the same topic"

"It is useful to see how my peers think."

"Helps me get outside perspective on my paper (after working on it for a while, I have become myopic to my flaws)."

"Feedback allows us to question and adjust our ideas (arguments)"

"The session has allowed me to listen to what others think about the same issue."

"Allows me to see blind spots l'd never have spotted myself."

"Offer alternative views - broadens horizon and adds complexity."

"Learning other perspectives can help me solidify my own reasoning."

"It is useful to have others' counter arguments to consider."

“Others' perspectives make me reconsider my judgments.”

"Hearing others voice their thoughts gave me insights into how they have shaped their thoughts."

In this way, learners not only evaluated one another's argument, but also their own. Such reflective judgment involves the ability of an individual to acknowledge that their views might be falsified by additional evidence obtained subsequently (Hoffman, 2016). This promoted epistemic cognition, what Hoffman (20I6) describes as recognizing the limits of knowing, the certainty of knowing, and the criteria for knowing. According to Hoffman (20l6), reflecting on one's own and others' arguments will improve argument and argument-related reasoning. More than that, in trying to make sense and reconcile their positions with others', learners better appreciated the nature of argumentation and how they needed to "perform" in this craft. Providing this "liminal space" in which students needed to grapple with "trou- blesome knowledge" (Meyer \& Land, 2006) took them out of their comfort zone and such "genuine, open debate of complex issues" fosters an understanding of the nature and construction of knowledge (Kuhn, 1991).

Results show that majority of these novice writers found that the feedback from the community had helped them to better refine their thesis statements (see Figure 7).

The goal of the CBF exercise is not for the community to reach consensus, but for each presenter to listen to and evaluate varying positions relative to his/her own. This process required the learner to re-calibrate his/her position by evaluating his/ her own reasoning, a process Kuhn (199I) terms as "thinking as argument". Having to defend his/her preliminary position, learners were motivated to adapt and negotiate their knowledge and understanding past the "state of liminality", defined as "a suspended state in which understanding approximates a kind of mimicry or lack of authenticity" (Meyer\& Land, 2006, p. 16) to eventually gain insights that deepened his tacit understanding of argumentation and appreciate the hidden connections. Excerpt I is an example of one such interaction:

\section{Excerpt 1}

On the topic of the moral permissibility of the death penalty,

Student A (feedback):Your argument is that using the death penalty as a deterrent against murder is not morally permissible as being used as a tool is dening theperson of his dignity. My argument however, is contrary to this. I am arguing that by killing someone, the murderer has forfeited his rights to be treated with dignity.

Student B (in response): But you would need to justify that it is moral to have his right to dignity forfeited.

Student A (in defence):That's because he has taken a life and that is morally wrong.

Student B (in response):That's a sweeping statement. What if it is in self-defence? If he does not kill, he will be killed. Is that morally wrong?

Student $C$ (in response):What do you both mean by "morally wrong"? Is it the same as morally permissible?

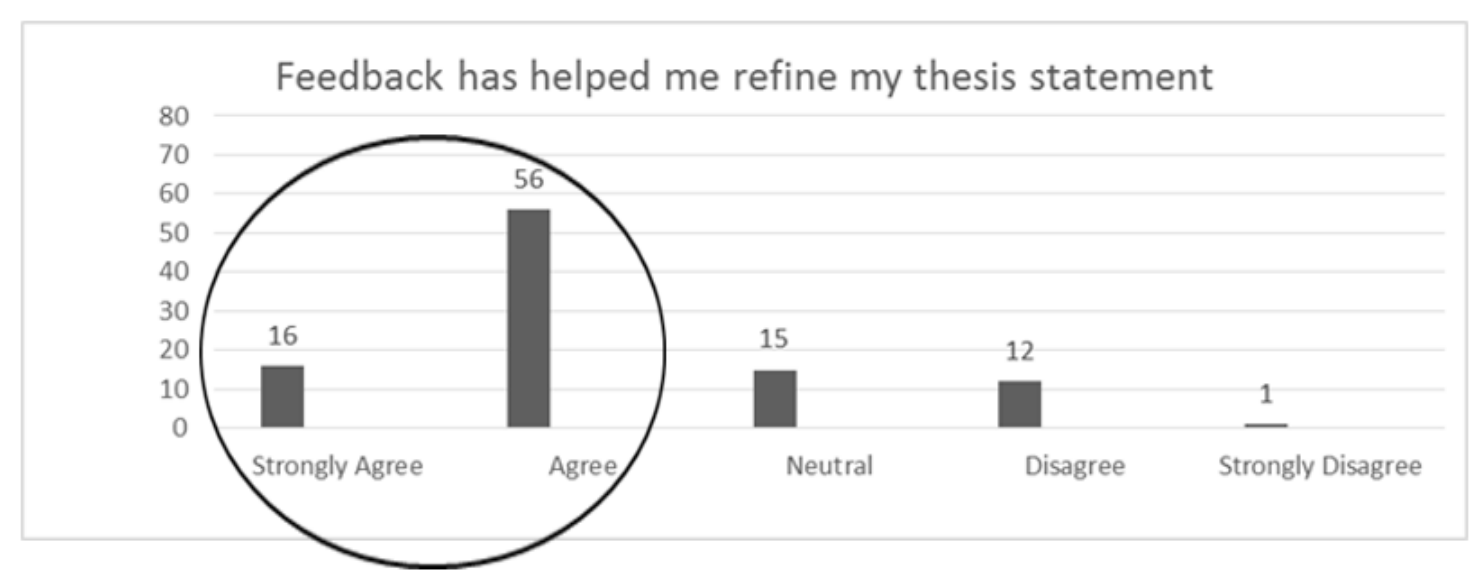

Figure 7: Impact when refining thesis statement 
As the teacher, I found it heartening to see students moving away from a simplistic agree/disagree dichotomy and begin to construct more nuanced positions. Such discourse helped learners make meaningful connections between their initial theoretical understanding of arguments in academic writing, and the real-life practice of how these connections work to support and defend a position, and to manage alternative views. One respondent commented that it "allowed him to apply theories and concepts to real life situations". "Engagement was increased, and learning was deepened as decision-making and reasoning was taken from a quick and intuitive level to a "more controlled mode of thinking (that is required) for the performance of unfamiliar tasks, the processing of abstract concepts and the deliberate application of rules." (Hoffman, 2016, p. 374). Critiquing and offering feedback to other writers' arguments encouraged the reviewers to question their own biases and assumptions and appreciate that the nature of argumentation included "web of conventions and assumptions" that is "largely tacit" (Shaughnessy, I 977, p. I39). Excerpt 2 is an example:

\section{Excerpt 2}

On the topic of the moral permissibility of the death penalty,

Student A (making a claim): The state does not have the right to take away someone's life as the death penalty violates the basic human right to live.

Student B (feedback): I think you need to consider the difference in saying "someone's life should not be taken" and "the state does not have the right to take awayone's life".

Student C (adding on): In this case, you can argue as it is a basic human right to live, one's life should not be taken away but it may be clearer if you further defined the role of the state here.

Student A (responding to feedback): Thanks, I see it now. In fact, I can strengthen my argument; no one has the right to kill because it takes away a person's right to live. If the role of the state is to protect its citizen's rights, then the death penalty goes against the duties of a state. That adds more to my argument. Thanks.
As a result, these novice writers were able to construct stronger arguments (see Figure 8). Sixteen percent of respondents strongly agreed, while forty-seven percent agreed that the feedback had helped them construct stronger arguments to support their position for their research papers.

The process of convincing others, and being convinced, presented learners with opportunities to perform arguments and defend their position, thus reinforcing the understanding of concepts and strategies associated with argumentation. By the end of the CBF exercise, each CLP would have worked through fifteen presentations sessions, giving members sufficient experience to internalize an argument schema (Reznitskaya, Anderson \& Kuo, 2007) that was modelled after practice. With each session, learners deepened their learning and were able to modify their schema to effectively transfer and apply what they have learnt to meet their needs when drafting their research paper.

By the end of the CBF exercise, learners' experiences made them more mature when making decisions in the writing process. Maturity is defined as the disposition to "(approach) problems, inquiry and decision making with a sense that some problems are necessarily ill-structured, some situations admit more than one plausible option, and many times judgments must be made based on standards, contexts and evidence which preclude certainty." (Facione et. al., 1995, p. 9). Responses such as

"It provided various components - critical thinking, synthesis, that all together makes me aware of how to better write a whole research essay."

"Realize how claim and evidence can be developed into different arguments by different writers."

"I understand what we need to do - to achieve an academic writing style."

indicated that learners had acquired an understanding of what Shaughnessy (1977) termed "rituals and ways of winning arguments in academia" to apply argumentation effectively to the demands of academic writing. Overall, seventy-seven percent of respondents found the CBF exercise useful in helping them write their research papers (see Figure 9).

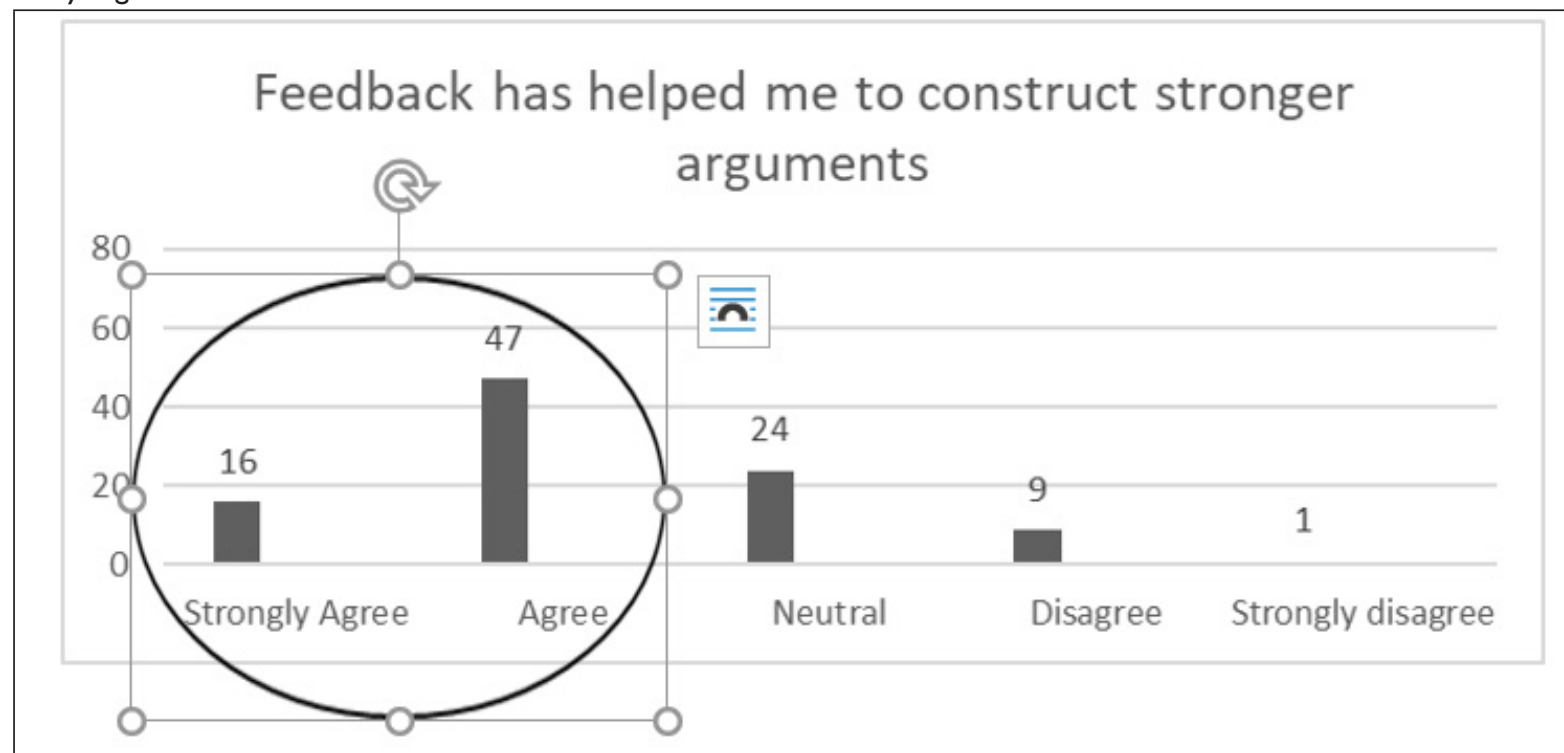

Figure 8. Impact of giving and receiving feedback on argument construction 


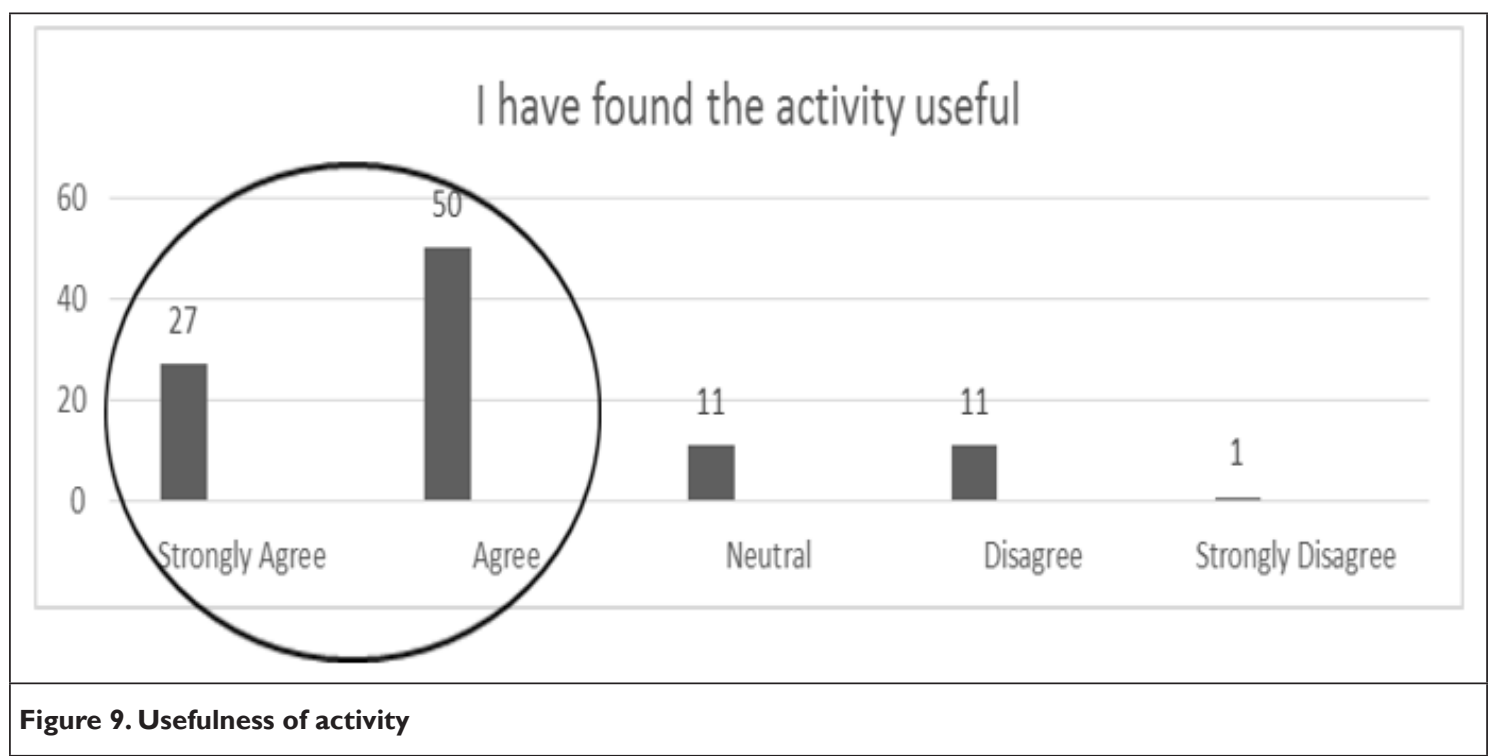

\section{DISCUSSION}

In this academic writing class, the dynamics of learning in a CLP changed students' perceptions and positively impacted the way they learnt. Students realised that learning is not absorption of knowledge; they learnt not to expect ready answers. Instead, they explored the complexities of academic writing and developed a more mature understanding of research. This peer review exercise was what Aitchinson \& Lee (2006) terms "a pedagogical space for experimenting and for articulating the struggle between knowledge and identity" (p. 273). Academic writing in undergraduate studies needs to be perceived as a practice that has the important role of complementing knowledge production, in most disciplines. Learners need to develop more holistically as academic writers acquiring "appropriate and effective use of literacy as more complex, dynamic, nuanced, situated, and involving both epistemological issues and social processes" (Lea \& Street, 2006, p. 369), not just as students in a writing class. Having critical thinking dispositions directs students' performance and facilitate their growth in the practice. When introduced at a freshmen level, it gives a longer runway to incorporate newcomers into academia and contribute to ongoing academic discourse.

This has implications on curriculum design. This study has shown that to enculturate learners into the practice, they need to work on the complexities of a "wicked" problem that is meaningful to the learners within a CLP.To achieve the critical engagement needed to deepen learning in a freshmen academic writing classroom, these novices needed to experience the practice of academic writing and all its complexities.

Learning in a CLP goes beyond learning in a group and is more than just having collaborative activities in the classroom. Unlike in a typical CoP (Wenger, 1998), where "wicked" problems (to borrow the term from Rittel and Webber, 1973) and are usually inherent in the nature of the professional communities, these CLPs are not organic, naturally occurring communities. It is therefore important to engage learners by providing create opportunities for learners to engage in "wicked" problems that are meaningful, yet and sufficiently complex and "troublesome" to fuel discussion, negotiation and debate.Wenger (1998) terms this "shared repertoire" which consists of "routines, words, tools, ways of doing, stories, gestures, symbols, genres, actions and concepts the community has produced or adopted" (p. 83) and these become resources for negotiating meaning. In an Asian context where students' experience of learning is generally teacher-centric, the devolvement of power from the teacher to their peers in a community of learners will bring about changes in mind-set and attitudes towards students' role as academic writers. This study has shown that critical engagement in a CLP can empower learners with the desired critical learning dispositions and skills to better position themselves in academic dialogue.

The grooming of critical thinking dispositions is of particular importance in today's rapidly changing world. As universities update their curricula, educators are placing greater emphasis on learner independence to encourage a "learning how to learn" mindset (Allison \&Wu, 200 I, p. 54). For these reasons, the reframing of learning from a structure-driven approach to a community-based experience will enhance criticality, as well as prepares learners to handle future "wicked' problems that they will face. After all, argumentation is "closely connected to the operation of the mind, to social interaction, to politics, and also to change and the exploration and resolution of difference or controversies." (Andrews, 2010, p. 38) Today, the role of education is to equip students with the ability to think critically, and to develop in them these dispositions as a "the default mode" (Halpern, 1999). This study has shown that such dispositions and skills can be cultivated given a conducive learning context.

The adoption of CoP practices into the classroom is not new, and when adapted to the Singapore context, has the potential to enrich students' learning experiences. This study is only the first stage that looks at how a strategically designed task in an CLP (an adaptation of the CoP) context can positively shape these learners' critical thinking dispositions in a Singapore classroom. This paper acknowledges that while it enhances learning by shaping critical thinking dispositions, such dispositions does not necessarily lead to good performance. The next step is to investigate how such dispositions affect performance. The CBF exercise is one of many experiences in this learning journey. It would also be interesting to find out how resilient these dispositions are and whether, and how these dispositions affect learning across various disciplines. 


\section{REFERENCES}

Aitchison, C., \& Lee, A. (2006). Research writing: Problems and pedagogies. Teaching in Higher Education, I I (3), 265-278. doi: I0.1080/|35625/0600680574

Allison, D., \& Wu, S.M. (200I). Academic writing: Whose expectations? RELC Journal, 32(I), 52-72. doi:I0.II 77/003368820I03200I04

Andrews, R. (2010). Argumentation in higher education: Improving practice through theory and research. New York: Routledge.

Baeten, M., Kyndt, E., Struyven, K., \& Dochy, F. (2010). Using student-centred learning environments to stimulate deep approaches to learning: Factors encouraging or discouraging their effectiveness. Educational Research Review, 5(3), 243-260. doi: 10.1016/j.edurev.2010.06.001

Burbules, N.C., \& Berk, R. ( 1999) Critical Thinking and Critical Pedagogy: Relations, Differences, and Limits. In Popkewitz T.S., \& Fendler, L. (Eds.), Critical Theories in Education, New York: Routledge, http://faculty.education.illinois.edu/burbules/papers/critical.html

Dahlgren, L. O.,A. Fejes, M.Abrandt-Dahlgren, and N.Trowald. 2009. "Grading Systems, Features of Assessment and Students' Approaches to Learning." Teaching in Higher Education I 4 (2): I85-194. doi: I0. I080/I35625 I0902757260.

Demirel, M. 2009. "Lifelong Learning and Schools in the Twenty-first Century." Procedia - Social and Behavioral Sciences I (I): 1709-1716. doi:10.1016/j.sbspro.2009.01.303

Dwyer, C. P., Hogan, M. J., Harney, O. M., \& Kavanagh, C. (20I7). Facilitating a student-educator conceptual model of dispositions towards critical thinking through interactive management. Educational Technology Research and Development, 65(I), 47-73. I0.1007/s I | 423-0 I6-9460-7

Facione, P.A., Sánchez, C.A., Facione, N. C., \& Gainen, J. (1995). the disposition toward critical thinking. The Journal of General Education, 44(I), I-25.

Felton, M., \& Kuhn, D. (200I). The development of argumentative discourse skill. Discourse Processes, 32(2-3), I35-I53. do i: 10.1080/0163853X.2001.9651595

Halpern, D. F. (1999). Teaching for critical thinking: Helping college students develop the skills and dispositions of a critical thinker. New directions for teaching and learning, 1999(80), 69-74.

Hoffman, M. H. G. (20I6). Reflective argumentation:A cognitive function of arguing. Argumentation, 30(4), 365-397. doi: I0.1007/s | 0503-015-9388-9

Hyland, K., \& Sancho-Guinda, C. (20I2). Stance and voice in academic writing. London: Palgrave. DOI, I0, 978 I I 370308

Johnson, D.W., \& Johnson, R. T. (2009). An educational psychology success story: Social interdependence theory and cooperative learning. Educational Researcher, 38(5), 365-379. doi: I0.3102/0013189x0933905725.

Kolb, D.A. ( 1984). Experiential learning: Experience as the source of learning and development. Englewood Cliffs, N.J: Prentice-Hall.

Kuhn, D. (199|). The skills of argument. Cambridge: Cambridge University Press.

Lea, M. R. \& Street B.V. (2006) The "academic literacies" model: Theory and applications. Theory Into Practice, 45(4), 368-377, doi: I0.1207/s I 543042 I tip4504_I I
Li, L., Liu, X., \& Steckelberg, A. L. (2010). Assessor or assessee: How student learning improves by giving and receiving peer feedback. British Journal of Educational Technology, 4 I (3), 525-536. doi: I 0. I I I I/j. I467-8535.2009.00968.x

Lillis, T., \& Scott, M. (2007). Defining academic literacies research: issues of epistemology, ideology and strategy. Journal of Applied Linguistics, 4(I), 5-32. https://doi-org.libproxyl.nus. edu.sg/I0.1558/japl.v4il.5

Liu, X., \& McCabe, A. (20I8). Attitudinal evaluation in Chinese university students' English writing:A contrastive perspective. Springer. doi: 10.1007/978-981-10-64 I5-9

Meyer, J., \& Land, R. (2006). Overcoming barriers to student understanding:Threshold concepts and troublesome knowledge. Abingdon, Oxon;New York;: Routledge.

McKeachie,W. J., \& Hofer, B. K. (2002). McKeachie's teaching tips: Strategies, research, and theory for college and university teachers (I I th ed.). Boston: Houghton Mifflin Co.

Polanyi, M. (1983). The tacit dimension. Gloucester, Mass: Peter Smith.

Reznitskaya,A., Anderson, R., \& Kuo, L. (2007). Teaching and learning argumentation. The Elementary School Journal, 107(5), 449-472. doi:10.1086/518623

Rittel, H., \& Webber, M. (1973). Dilemmas in a general theory of planning. Policy Sciences, 4, I55e I 59.

Shaughnessy, M. P. (1977). Errors and expectations:A Guide for the Teacher of Basic Writing. New York: Oxford University Press.

Siegel, H. ( 1 988). Educating reason: Rationality, critical thinking, and education. New York: Published by Routledge in association with Metheun.

Sullivan, P. (20I4). A new writing classroom: Listening, motivation, and habits of mind. University Press of Colorado.

Tan, C. (20I7). Teaching critical thinking: Cultural challenges and strategies in Singapore. British Educational Research Journal, 43(5), 988-1002. doi:10.1002/berj.3295

Topping, K. (1998). Peer assessment between students in colleges and universities. Review of Educational Research, 68(3), 249-276. doi: I0.3102/00346543068003249

Trigwell, K., Prosser, M., \& Waterhouse, F. (1999). Relations between teachers' approaches to teaching and students' approaches to learning. Higher Education, 37(I), 57-70. doi: I0.1023/A: I0035483 |3194

Vygotsky, L. S., \& Cole, M. (1978). Mind in society:The development of higher psychological processes. Cambridge: Harvard University Press.

Wenger, E. (1998). Communities of practice: Learning, meaning, and identity. Cambridge, U.K;New York, N.Y;: Cambridge University Press.

Wenger, E. (20I I). Communities of practice:A brief introduction. STEP Leadership Workshop, University of Oregon, October 201 I [6]. Retrieved from http://hdl.handle. net/I794/II736

Wingate, U. (20I2). 'Argument!' helping students understand what essay writing is about. Journal of English for Academic Purposes, I I (2), I 45-I54. doi: I 0.I 0 I6/j.jeap.20 I I.I I.00 I 